\title{
PEMBANGUNAN DESA WISATA GADINGAN DAN KEBUTUHAN PENGEMBANGAN SUMBER DAYA MANUSIA DALAM PENDEKATAN COMMUNITY BASED TOURISM
}

\section{RURAL TOURISM OF GADINGAN AND THE NEED FOR HUMAN RESOURCES DEVELOPMENT IN A COMMUNITY BASED TOURISM APPROACH}

\author{
${ }^{1)}$ Winda Amilia, ${ }^{2)}$ Rokhani, ${ }^{3)}$ Rendra C. Prasetya, ${ }^{4}$ Bertung Suryadharma \\ ${ }^{1,4)}$ Fakultas Teknologi Pertanian, Universitas Jember. Jalan Kalimantan No. 37, Jember 68121, Indonesia \\ ${ }^{2)}$ Fakultas Pertanian, Universitas Jember. Jalan Kalimantan No. 37, Jember 68121, Indonesia \\ ${ }^{3)}$ Fakultas Kedokteran Gigi, Universitas Jember. Jalan Kalimantan No. 37, Jember 68121, Indonesia
}

*Korespondensi Penulis. Email: winda.ftp@unej.ac.id

Telp: +6287757555099

\begin{abstract}
ABSTRAK
Pariwisata adalah kebutuhan manusia. Pariwisata membuka peluang bagi pemerintah daerah dan masyarakat untuk memanfaatkan sumberdaya alam dan kekayaan budaya sebagai sajian wisata. Desa Gadingan di Kabupaten Situbondo memiliki potensi sumberdaya alam dan budaya yang dapat dikembangkan sebagai desa wisata. Potensi tersebut didukung oleh aksesibilitas dan obyek wisata lain yang ada di sekitas desa Gadingan. Masalah yang teridentifikasi yaitu rendahnya kapabilitas masyarakat dalam identifikasi potensi, perencanaan, dan pengelolaan desa wisata. Tujuan pelaksanaan kegiatan ini adalah mengembangkan kemampuan manajerial sumberdaya manusia desa Gadingan dalam pengidentifikasian dan perencanaan potensi serta pengelolaan desa wisata. Metode pelaksanaan kegiatan dengan Focus Group Discussion (FGD) penyuluhan, pelatihan, dan pendampingan bagi masyarakat penggerak desa wisata. Hasil analisa potensi wisata dengan metode FGD yaitu pantai Gadingan sebagai wisata utama, pemilihan pasar ikan Jangkar, embung Gadingan, dan pelabuhan syahbandar sebagai wisata pelengkap, serta Sholawat Nariyah sebagai wisata penunjang.
\end{abstract}

Kata kunci: pariwisata; desa wisata; sadar wisata; atraksi wisata; pokdarwis

\section{ABSTRACT}

Tourism is a human need. Tourism provide an opportunities for local governments and communities to optimize natural resources and culture as tourism object. Gadingan is a village in Situbondo Regency. It has natural and cultural resourcesto be developed as rural tourism. The problem identified was the low capability of the community in identifying and planning the potential destination, and lack of management skills of rural tourism. The aim of the study to develope human resources managerial skills for rural tourism in Gadingan. Itroduction of the potential and management of the tourism village. The methodology are discussion, counseling, training, and mentoring for the rural tourism community. Results of the study (1) Gadingan beach identified as the main tourism superstructure, (2) Jangkar's fish market,, Gadingan's reservoir, and syahbandar port identified as the supplementing tourism superstructuret, and (3) Sholawat Nariyah identified as supporting tourism.

Keywords: tourism; rural tourism; tourism aware; tourism attraction; pokdarwis

Submitted : 8 April 2019 Revision : 7 November 2019 Accepted : 17 Februari 2020 


\section{PENDAHULUAN}

Rekreasi dan pariwisata adalah kebutuhan yang tidak dapat dipisahkan dari kehidupan manusia modern. Keragaman budaya dan keindahan alam di Indonesia menjadi modal bagi daerah untuk mengembangkan potensi pariwisata. Sehingga, pariwisata juga telah menjadi salah satu primadona bagi daerah untuk meningkatkan sumber pendapatannya.

Kawasan wisata dapat berkembang jika memiliki (1) aksesibilitas yang baik, (2) obyek menarik berupa alam, seni budaya, legenda, makanan lokal dan sebagainya, (3) dukungan masyarakat dan perangkat desa, (4) keamanan yang terjamin, (5) tersedia akomodasi dan telekomunikasi, (6) berhubungan dengan obyek wisata lain yang telah dikenal masyarakat luas (Hadiwijoyo, 2012; Syafi'i dan Suwandono, 2015). Komponen-komponen tersebut telah dimiliki desa-desa di kecamatan Jangkar sebagai modal dasar pengembangan desa wisata. Kecamatan Jangkar yang berada di jalur lintas utama trans Jawa - Bali memiliki akses yang mudah dijangkau, didukung oleh potensi alam dan budaya masyarakat yang dapat dikembangakan sebagai kawasan wisata.

Desa Gadingan di Kecamatan Jangkar Kabupaten Situbondo memiliki potensi untuk dikembangkan sebagai destinasi wisata baru berupa desa wisata. Sumberdaya alam, aspek sosial budaya dan aksesibilitas yang baik merupakan modal awal yang mendukung pengembangan kawasan tersebut sebagai kawasan desa wisata (Zakaria \& Suprihardjo, 2014). Pengembangan desa wisata dapat membawa dampak positif bagi masyarakat yaitu membuka peluang lapangan pekerjaan baru, menggerakkan roda ekonomi, meningkatkan kelestarian alam dan budaya desa (A'inun, Krisnani, dan Darwis, 2015). Pengembangan desa wisata membutuhkan interaksi antar aktor yang berperan dalam menggerakkan sistem. Secara umum, terdapat tiga pilar utama dalam pengembangan pariwisata yaitu masyarakat, swasta, dan pemerintah (Rani, 2014). Ketiga pilar tersebut harus bersinergi untuk memberikan dampak positif pengembangan pariwisata, terutama desa wisata.

Pengembangan desa wisata di desa Gadingan merupakan stimulus untuk pembangunan desa yang mandiri dan peningkatan kualitas sumberdaya manusia. Undang-Undang Nomor 10 tahun 2009 tentang Kepariwisataan menyatakan bahwa penyelenggaraan kepariwisataan ditujukan untuk meningkatkan pendapatan nasional dalam rangka meningkatkan kesejahteraan dan kemakmuran rakyat, memperluas dan memeratakan kesempatan berusaha dan lapangan kerja. Dalam Undang-Undang tersebut terlihat peran sumberdaya manusia tidak dapat dilepaskan dari pembangunan pariwisata. Masyarakat di desa Gadingan belum memiliki pengetahuan dan ketrampilan dalam pariwisata karena latar belakang penduduk yang bekerja sebagai petani dan nelayan. Konsep pembangunan pariwisata dan pembangunan sumberdaya manusia tersebut sesuai dengan konsep Community Based Tourism (CBT) yang akan membuka peluang terbentuknya jenis mata pencaharian serta sumber pendapatan yang baru bagi masyarakat (Qiqi \& Rova, 2014).

Konsep dalam CBT serupa dengan konsep pemberdayaan masyarakat, artinya masyarakat distimulus untuk mengenali potensinya dan selanjutnya dilatih untuk mengembangkan potensi tersebut dalam pengelolaan desa wisata. Konsep CBT (Community Based Tourism) juga sejalan dengan konsep gotong royong yang merupakan bentuk kerjasama kelompok masyarakat yang menjadi budaya asli Indonesia yang telah tumbuh dan berkembang secara turun temurun (Effendi, 2013). Dalam konsep CBT terdapat aktivitas institusi lokal yang memfasilitasi partisipasi masyarakat dan mengembangkan kelompok masyarakat (Aref, Gill, dan Aref, 2010). Institusi lokal tersebut dalam buku pedoman yang diterbitkan oleh Kementerian Pariwisata dan Ekonomi Kreatif tahun 2012 merujuk pada kelompok sadar wisata (Pokdarwis).

Keberhasilan pengembangan desa wisata dengan pendekatan CBT ditentukan oleh kepemimpinan, pengelolaan yang efektif, partisipasi aktif masyarakat, daya dukung dan komitmen masyarakat, kebersamaan dan dukungan pemerintah (Giampiccoli dan Kalis, 2012). Dalam pengembangan pariwisata dengan pendekatan Community Based Tourism (CBT) peran masyarakat adalah elemen penting. Qiqi \& Rova (2014) menyatakan 
bahwa pariwisata adalah kegiatan yang ditawarkan oleh manusia untuk manusia, dan pariwisata memberikan peluang terbukanya lapangan pekerjaan baru namun cenderung menjadi sektor dengan produktivitas rendah jika tidak diimbangi dengan peningkatan kemampuan pelakunya,

Masyarakat desa Gadingan dengan latar belakang masyarakat yang bermata pencarian sebagai petani dan nelayan belum memiliki kesadaran tentang peran dan tanggung jawab masyarakat dalam pembangunan desa wisata. Dalam pembentukan kesadaran peran dan tanggung jawab masyarakat ini memerlukan tindakan inisiasi oleh Kelompok Sadar Wisata (Pokdarwis). Pokdarwis yang ada di desa Gadingan masih merupakan bentuk inisiasi awal, dan belum disahkan sebagai sebuah kelembagaan. Oleh karena itu tujuan pelaksanaan pemberdayaan masyarakat di desa Gadingan adalah untuk mengembangkan ketrampilan masyarakat dalam mengenali potensi lingkungan, perencanaan dan pengembangan desa wisata secara mandiri.

\section{METODE}

Mitra pengembangan desa wisata Gadingan adalah Pemerintah Desa Gadingan, Pemerintah Kecamatan Jangkar, dan masyarakat calon penggerak wisata desa. Pemerintah Desa Gadingan dan Pemerintah Kecamatan Jangkar berperan dalam penyusunan kebijakan dan anggaran dalam pengembangan desa wisata yang disepakati dalam kegiatan Musyawarah Perencanaan dan Pengembangan Desa (Musrenbang). Masyarakat yang terlibat dalam kegiatan ini sejumlah 14 orang yang terdiri dari 9 orang karang taruna, 3 orang tokoh masyarakat dan 1 orang tokoh agama. Musrenbang telah menyepakati peran Karang Taruna sebagai Kelompok Sadar Wisata (Pokdarwis) desa Gadingan yang bertanggung jawab pada pengelolaan destinasi dan atraksi wisata. Keterlibatan tokoh agama dan tokoh masyarakat berperan dalam pendekatan kemasyarakatan secara luas, karena karakteristik masyarakat desa Gadingan yang kental dengan nuansa keagamaan dan kebersamaan.

Permasalahan di desa Gadingan diselesaikan dengan mengadopsi model
Community Based Tourism yang berarti dengan mengutamakan pendekatan partisipatif. Pendekatan partisipatif dilakukan dengan focus group discussion, penyuluhan, pelatihan dan pendampingan. Kegiatan pemberdayaan masyarakat di desa Gadingan secara terstruktu dilaksanakan dengan:

\section{Focus Group Discussion}

Focus Group Discussion atau FGD dilakukan untuk membangun partisipasi masyarakat dalam mengenali potensi wilayahnya serta melakukan penyusunan skala prioritas pengembangan. Penetapan potensi dilakukan dengan teknik pembobotan dan analisa skoring dengan menggunakan skala likert. Obyek yang dinilai dianalisis sesuai kriteria penskoringan dengan menggunakan rumus:

$$
\mathrm{S}=\mathrm{N} \times \mathrm{B}
$$

Keterangan: $\mathrm{S}=$ skor

$$
\begin{aligned}
& \mathrm{N}=\text { jumlah nilai } \\
& \mathrm{B}=\text { bobot nilai }
\end{aligned}
$$

2. Penyuluhan

Penyuluhan bertujuan untuk merubah mindset masyarakat, membangun masyarakat sadar wisata, memahami prinsip sapta pesona dalam pariwisata, serta membangun kesadaran pentingnya peran Pokdarwis. Penyuluhan dilakukan untuk menunjukkan kepada masyarakat contoh pembangunan desa wisata dan dampak positif yang diperoleh dari upaya pembangunan desa wisata. Penyuluhan dilakukan dengan menunjukkan gambar serta video desadesa wisata yang telah berhasil berkembang dengan peran Pokdarwis dan masyarakat.

3. Pelatihan

Pelatihan bertujuan untuk meningkatkan kemampuan masyarakat untuk mengenali masalah dan menyelesaikan masalah dalam pengembangan desa wisata. Metode yang diajarkan adalah penggunaan Metaplan. Pelatihan pengelolaan lingkungan dilakukan dengan melatih masyarakat memanfaatkan sampah 
sebagai bahan pembuatan atraksi wisata di pantai Gadingan.

4. Pendampingan

Metode pendampingan bertujuan untuk menjaga keberlangsungan (sustainability) masyarakat dalam mengembangkan desa wisata di wilayah desa Gadingan.

Empat metode tersebut digunakan dalam pengenalan potensi wilayah desa Gadingan, pembangunan karakter sadar wisata, upaya pembentukan kelompok sadar wisata (Pokdarwis), dan pengembangan atraksi wisata.

\section{HASIL DAN PEMBAHASAN}

Pariwisata tidak dapat dipisahkan dari aktivitas manusia. Pembangunan pariwisata berarti juga pembangunan manusia khususnya bagi pelaku pariwisata. Dalam pendekatan konsep CBT desa wisata dikembangkan melalui pemberdayaan masyarakat lokal, dimana masyarakat turut andil dalam perencanaan, pengelolaan, dan pengambilan keputusan dalam pembangunannya. Menurut Novaria dan Rohimah (2017) dalam konsep CBT terdapat tiga aktivitas pariwisata yang sesuai untuk dikembangkan yaitu aktivitas penjelajahan (adventure travel), wisata budaya (cultural tourism) dan ekowisata (ecotourism).

\section{a. Pengenalan Potensi Wilayah Desa Gadingan}

Dalam pelaksanaan kegiatan pemberdayaan masyarakat selama ini sering mengalami kegagalan karena tidak ada atau kurangnya keterlibatan masyarakat mulai dari tahap awal penyusunan rencana, sehingga pemberdayaan masyarakat sering tidak relevan dengan kebutuhan masyarakat (Sanusi \& Hidayah, 2015). Berdasarkan hal tersebut maka untuk melaksanakan kegiatan pemberdayaan masyarakat di desa Gadingan memerlukan berbagai data dan informasi yang berkaitan dengan potensi yang dimiliki desa. Informasi potensi desa dan permasalahannya dapat diperoleh secara partisipatif dari masyarakat yang ada di desa tersebut. Metode yang paling sesuai untuk itu adalah Participatory Rural Appraisal (PRA).

Kunci pengembangan desa wisata adalah penemuan potensi desa yang terkait dengan seni, budaya, kebiasaan masyarakat sehari-hari, makanan khas, maupun sumber daya alam (Zakaria dan Suprihardjo, 2014). Masyarakat desa Gadingan diajak secara aktif dalam sebuah Focus Group Discussion menentukan potensi-potensi yang ada di wilayahnya. Potensi-potensi yang teridentifikasi adalah pantai Gadingan, embung Gadingan, pasar ikan Jangkar, serta Pelabuhan Syahbandar Jangkar. Indikator yang digunakan dalam pemetaan adalah daya tarik wisata, aksesibilitas, sarana prasarana, dan kepemilikan lahan. Berdasarkan kuisioner yang digunakan dalam FGD, diperoleh hasil skoring potensi wisata seperti pada tabel 1 .

Tabel 1. Skoring potensi wisata

\begin{tabular}{llllllll}
\hline Destinasi & & $\begin{array}{l}\text { Daya } \\
\text { Wisata }\end{array}$ & Tarik & Aksesibilitas & $\begin{array}{l}\text { Sarana } \\
\text { Prasarana }\end{array}$ & $\begin{array}{l}\text { Kepemilikan } \\
\text { Lahan }\end{array}$ & $\begin{array}{l}\text { Skor } \\
\text { Total }\end{array}$ \\
\hline Pantai & Nilai & 57 & 50 & 31 & 62 & \\
Gadingan & Bobot & 35 & 25 & 25 & 15 & \\
& Skor & 1995 & 1250 & 775 & 930 & 4950 \\
Embung & Nilai & 54 & 39 & 27 & 50 & \\
Gadingan & Bobot & 35 & 25 & 25 & 15 & \\
& Skor & 1890 & 975 & 675 & 750 & 4290 \\
Pasar Ikan & Nilai & 40 & 43 & 33 & 28 & \\
& Bobot & 35 & 25 & 25 & 15 & \\
& Skor & 1400 & 1075 & 825 & 420 & 3720 \\
Pelabuhan & Nilai & 48 & 56 & 45 & 28 & \\
Syahbandar & Bobot & 35 & 25 & 25 & 15 & \\
& Skor & 1680 & 1400 & 1125 & 420 & 4625 \\
\hline
\end{tabular}


Dari tabel 1 di atas, dapat diketahui bahwa masyarakat berpendapat bahwa potensi wisata tertinggi adalah pantai Gadingan. Wisata pantai Gadingan merupakan wisata utama di desa
Gadingan, sedangkan destinasi yang lain merupakan wisata pendukung. Destinasi wisata di desa Gadingan dapat dipetakan seperti pada tabel 2 .

Tabel 2. Pemetaan potensi wisata

\begin{tabular}{llllll}
\hline & \multicolumn{2}{c}{ Kondisi Sebelum FGD } & & \multicolumn{3}{c}{ Kondisi Sesudah FGD } \\
\hline Wisata & Wisata & Wisata & Wisata & Wisata & Wisata \\
Utama & Pelengkap & Penunjang & Utama & Pelengkap & Penunjang \\
\hline Belum & Belum & Pengajian & Pantai & Pasar ikan & Pengajian \\
teridentifikasi & teridentifikasi & Sholawat & Gadingan & Jangkar, & Sholawat \\
& & Nariyah & & Embung & Nariyah \\
& & & Gadingan, & \\
& & & & Pelabuhan & \\
& & & & Syahbandar & \\
& & & & \\
\hline
\end{tabular}

Menurut Primadany dkk. (2013), sarana pariwisata terbagi menjadi tiga bagian penting yaitu sarana pokok pariwisata, sarana pelengkap pariwisata, dan sarana penunjang pariwisata. Pengembangan potensi wisata desa Gadingan telah memenuhi aspek utama yaitu adanya wisata utama sebagai sarana pokok pariwisata, yaitu pantai Gadingan. Aksesibilitas secara umum sangat baik, namun untuk menjangkau pantai Gadingan diperlukan perbaikan jalan desa. Wisata pendukung sebagai sarana pelengkap pariwisata di desa Gadingan yaitu Pasar Ikan Jangkar, Embung
Gadingan, dan Pelabuhan Syahbandar. Keberadaan wisata utama dan wisata pelengkap masih perlu dilengkapi dengan keberadaan wisata penunjang yaitu pengajian sholawat Nariyah yang menjadi kebudayaan lokal yang dikenal oleh seluruh masyarakat tapal kuda. Keberadaan sarana-sarana tersebut menurut Primadany dkk. (2013) akan menyediakan kebutuhan pokok yang ikut menentukan keberhasilan suatu daerah dalam menjadi tujuan wisata. Pengenalan sarana pariwisata di desa Gadingan seperti pada tabel 3.

Tabel 3. Pengenalan sarana pariwisata

\begin{tabular}{ll}
\hline \multicolumn{1}{c}{ Aspek } & \multicolumn{1}{c}{ Keterangan } \\
\hline Alam & $\begin{array}{l}\text { Pantai Gadingan yang berpasir hitam, pemandangan sunset } \\
\text { yang indah, }\end{array}$ \\
\hline $\begin{array}{l}\text { Aksesibilitas (akses jalan menuju } \\
\text { obyek) }\end{array}$ & $\begin{array}{l}\text { Secara umum kondisi jalan sangat bagus, hanya sekitar 300 } \\
\text { meter sebelum pantai Gadingan jalan berupa jalan desa } \\
\text { (tanah berpasir) }\end{array}$ \\
\hline Kondisi jalan & $\begin{array}{l}\text { Dapat diakses dengan kendaraan pribadi atau menggunakan } \\
\text { bus Surabaya/Probolinggo/Situbondo yang menuju } \\
\text { Banyuwangi hingga pertigaan Jangkar. Lalu dilanjutkan } \\
\text { dengan ojek. }\end{array}$ \\
Sarana transportasi & Belum ada papan penunjuk arah \\
\hline $\begin{array}{l}\text { Senunjuk arah } \\
\text { obyek) }\end{array}$ & \\
\hline
\end{tabular}


Akomodasi

Rumah makan/warung

Tempat ibadah
Di wilayah desa Gadingan belum ada sarana penginapan. Namun di wilayah kecamatan Jangkar dapat ditemui penginapan kelas melati

Di sepanjang jalan menuju pantai Gadingan dapat ditemui beberapa rumah makan/warung

Di pantai Gadingan belum ada tempat ibadah (mushola) namun di wilayah pemukiman sekitar pantai tempat ibadah mudah ditemukan

Kamar mandi

Di pantai Gadingan belum dilengkapi dengan sarana kamar mandi

Ojek

Tidak ada

Jasa angkutan

Pos keamanan dan jasa pemandu

Aktivitas (kegiatan yang dapat dilakukan di obyek)

\begin{tabular}{ll}
\hline Menikmati pemandangan alam & Wisatawan \\
Memancing & Wisatawan \\
Mencari kerang & Wisatawan \\
Bermain layang-layang & Wisatawan \\
$\begin{array}{l}\text { Berjualan layang-layang atau } \\
\text { makanan }\end{array}$ & Warga masyarakat
\end{tabular}

Pantai Gadingan dapat dikembangkan sebagai sarana pokok pariwisata dengan ditunjang sarana-prasarana lainnya. Tabel 3 merupakan hasil pengenalan sarana pariwisata yang dilakukan melalui metode FGD bersama masyarakat. Partisipasi masyarakat dalam penyusunan sarana pariwisata desa Gadingan memberikan gambaran yang lebih nyata, seperti yang dikemukakan oleh Giampiccoli dan Kalis (2012) bahwa keterlibatan masyarakat secara sadar dan sukarela dalam proses pembangunan merupakan perwujudan kepedulian dan tanggung jawab yang bertujuan memperbaiki kualitas hidup masyarakat itu sendiri.

Hasil pengenalan sarana pokok pariwisata ditindaklanjuti dengan aktivitas bersih pantai yang diselenggarakan secara berkesinambungan setiap satu bulan sekali. Aktivitas bersih pantai tersebut merupakan perwujudan sikap gotong royong yang secara turun temurun merupakan budaya lokal di desa Gadingan. Effendi (2013) mengemukakan bahwa perwujudan budaya gotong royong perlu didorong oleh suasana sosial yang bisa ditempuh dengan meningkatkan kemampuan (capacity vuilding), menekankan pada otonomi (kemandirian) komunitas lokal, keswadayaan lokal (local self-reliance) yang bersifat partisapatoris. Partisipasi masyarakat adalah nyawa bagi berkembangnya desa wisata. Partisipasi masyarakat sangat ditentukan oleh tiga unsur pokok yaitu adanya kesempatan yang diberikan kepada masyarakat untuk berpartisipasi, adanya kemauan masyarakat untuk berpartisipasi, dan adanya kemampuan masyarakat untuk berpartisipasi. Untuk meningkatkan partisipasi masyarakat tersebut, pemerintah daerah harus secara aktif melakukan penyuluhan dan pelatihan sadar wisata, pelestarian lingkungan dan budaya, serta mengajak masyarakat mewujudkan sapta pesona (Primadany, Mardiyono, Riyanto, 2013).

Pengenalan potensi dan upaya tindak lanjut yang dilakukan masyarakat desa Gadingan sesuai dengan pendekatan konsep CBT. Masyarakat desa Gadingan telah melakukan pengembangan partisipasi masyarakat dalam menggali potensi, perencanaan dan tindak lanjut. Novaria dan Rohimah (2017) menyatakan bahwa pengembangan pariwisata berbasis CBT membutuhkan peran utama sumber daya manusia, karena sejatinya peningkatan kapabilitas sumberdaya manusia merupakan modal dasar dalam pembangunan. 


\section{b. Pengembangan Karakter Sadar Wisata}

Sadar wisata adalah suatu kondisi yang menggambarkan partisipasi dan dukungan segenap komponen masyarakat dalam mendorong terwujudnya iklim yang kondusif bagi tumbuh dan berkembangnya kepariwisataan di suatu daerah (Kementerian Pariwisata dan Ekonomi Kreatif, 2012). Kesadaran masyarakat desa Gadingan terhadap pariwisata telah terbentuk dengan dihasilkannya pemetaan potensi wisata desa dan upaya bersih pantai. Hal ini merupakan bentuk tanggung jawab dalam perannya sebagai tuan rumah dan sebagai pelaku wisata (Wijaya, Zulkarnain, dan Sopingi, 2016) dalam mewujudkan sapta pesona pariwisata (Kementerian Pariwisata dan Ekonomi Kreatif, 2012). Sapta pesona merupakan jabaran konsep sadar wisata yang terwujud dalam dukungan dan peran masyarakat sebagai tuan rumah pariwisata untuk menciptakan lingkungan dan suasana yang kondusif. Perwujudan sapta pesona yaitu terwujudnya unsur aman, tertib, bersih, sejuk, indah, ramah, dan kenangan.

Metode penyuluhan diterapkan dalam penyampaian materi sadar wisata dan sapta pesona. Masyarakat ditunjukkan faktor pendukung pengembangan pariwisata di desa Gadingan yang telah ditemukan pada tahapan sebelumnya yang bertujuan untuk meningkatkan kesadaran masyarakat terhadap potensi diri dan wilayahnya.

\section{c. Pembentukan Kelompok Sadar Wisata (Pokdarwis)}

Untuk membentuk sadar wisata dalam kerangka sapta pesona diperlukan penggerak pariwisata atau yang disebut dengan kelompok sadar wisata (Pokdarwis). Keberadaan Pokdarwis dalam konteks pengembangan destinasi pariwisata telah berperan sebagai salah satu "unsur penggerak" dalam turut mendukung terciptanya lingkungan dan suasana yang kondusif di wilayahya. Keberadaan Pokdarwis secara kolektif akan memberikan dampak positif bagi perkembangan wisata dalam konteks yang lebih luas.

Peran Pokdarwis dalam pembangunan desa wisata sangat menentukan arah pengembangan karena pada konsep CBT tersebut Pokdarwis berperan sebagai perencana, pengambil keputusan dan pelaku dalam pembangunan pariwisata. Perencanaan dan pengelolaan yang dilakukan oleh Pokdarwis akan memberikan hasil yang lebih baik karena proses perencanaan, pengambilan keputusan, dan pelaksanaan dilakukan oleh masyarakat sendiri berdasarkan pada pengalaman, permasalahan, dan peluang yang dirasakan oleh masyarakat. Hal ini berbeda dengan proses pembangunan dengan model top-down, dimana masyarakat tidak memiliki peluang untuk merencanakan dan mengambil keputusan yang pada pembangunan desa wisata akan memberikan tingkat keberhasilan yang lebih kecil (Sinh, Nga, Linh, Tuan, 2016).

Pariwisata merupakan hal baru bagi masyarakat desa Gadingan. Untuk itu, peran penting masyarakat dan Pokdarwis tersebut perlu terus didukung dan dikembangkan secara kualitas dan kuantitas untuk dapat menopang perkembangan pariwisata. Untuk membangun motivasi dan kesadaran pariwisata, dilakukan tahapan diskusi dan penyuluhan serta pemberian contoh-contoh sukses peran Pokdarwis dalam mengelola desa wisata. Desa wisata yang telah sukses tersebut antara lain desa Pujon Kidul di Kabupaten Malang, desa Nglanggeran di Kabupaten Gunung Kidul, dan desa Canggu di Kabupaten Kediri. Desa-desa tersebut mengembangkan desa wisata berbasis sumberdaya alam dalam pengelolaan Pokdarwis yang kemudian melahirkan peluang ekonomi baru melalui wisata kuliner, wisata petualangan, dan industri cinderamata.

Tahap diskusi dan penyuluhan yang disampaikan pada masyarakat desa Gadingan telah melahirkan kesadaran tentang pentingnya keberadaan Pokdarwis dalam pengembangan desa wisata di wilayah tersebut. Masyarakat bersama-sama menyepakati terbentuknya inisiasi Pokdarwis yang akan dibicarakan lebih lanjut pada kegiatan Musyawarah Perencanaan Pembangunan (musrenbang) desa Gadingan. Inisiasi Pokdarwis Gadingan dibentuk oleh masyarakat dan untuk masyarakat dengan ketentuan yang disepakati bersama. Ketentuan pembentukan Pokdarwis yang disepakati bersama yaitu 1). keanggotannya bersifat sukarela, 2). anggota adalah masyarakat yang bertempat tinggal di desa Gadingan, 3). anggota wajib memiliki komitmen dalam mengembangkan pariwisata Gadingan, 4). Kepengurusan terdiri dari pembina, penasehat, 
pimpinan (ketua, sekretaris, bendahara), anggota, dan seksi-seksi.

\section{d. Pengembangan Atraksi Wisata}

Keberadaan pantai-pantai di sekitar pantai Gadingan seperti pantai Banongan, pantai Pasir Putih, pantai Pathek, pantai Bama, pantai Tampora, dan pantai Tangsi merupakan faktor pendukung sekaligus faktor penghambat bagi pengembangan pantai Gadingan. Untuk dapat tampil sebagai salah satu destinasi wisata pantai maka pantai Gadingan harus berbenah. Salah satu strategi untuk mengembangkan pantai Gadingan adalah dengan menciptakan keunikan yang menjadi pembeda dengan keberadaan pantai lainnya.

Pengembangan atraksi wisata tersebut dilakukan melalui fase diskusi bersama dengan masyarakat. Tujuan dari aktivitas ini adalah melatih masyarakat untuk secara mandiri dan berkelanjutan menemukan serta mengembangkan keunikan bagi wilayahnya. Metode metaplan digunakan dalam FGD pengembangan atraksi wisata, dengan pelaksanaan sebagai berikut:

1. Warga yang pernah mengunjungi pantai Banongan, pantai Pasir Putih, pantai Pathek, pantai Bama, pantai Tampora, dan pantai Tangsi menyusun atraksi maupun aktivitas yang menarik dan tidak menarik di lokasi-lokasi tersebut. Warga menambahkan atraksi yang wisatawan saat ini sukai namun tidak ditemukan di lokasi-lokasi tersebut. Hasil temuan disusun di papan dengan menggunakan sticky notes.

2. Atraksi atau aktivitas yang menarik di lokasi tersebut namun sama dengan atraksi yang ada di pantai Gadingan ditarik kembali dari papan.

3. Atraksi atau aktivitas yang masih tersisa di papan kemudian disusun berdasarkan prioritas kepentingan dan kemudahan pelaksanaan.

Hasil FGD tersebut merupakan bentuk partisipasi masyarakat dalam pembangunan desa wisata di desa Gadingan. Program yang disusun oleh masyarakat akan mengembangkan ketrampilan dan pengetahuan yang tepat, sesuai dengan kebutuhan pasar dengan mempertimbangkan potensi pendukung yang ada di masyarakat itu sendiri (Hermawan dan
Suryono, 2016). Atraksi wisata yang direncanakan oleh masyararakat di untuk mengembangkan potensi wisata di Pantai Gadingan adalah pembuatan spot-spot foto yang menarik bagi wisatawan. Aktivitas penunjang wisata pantai Gadingan yang direncanakan masyarakat adalah upaya pelestarian lingkungan yang diwujudkan dengan program bersih pantai, pemasangan jaring pada muara sungai, dan rekayasa aliran muara sungai. Keberadaan pantai Gadingan dan spot foto merupakan upaya masyarakat dalam memberikan manfaat dan kepuasan bagi wisatwan. Seperti yang dikemukakan Zulfanita dan Setiawan (2015) bahwa penyediaan sarana yang nyata maupun tidak nyata yang diatur dan dikelola untuk memberikan manfaat bagi wisatawan merupakan sebuah potensi wisata. Pelestarian lingkungan yang dilakukan masyarakat desa Gadingan dalam mengelola pariwisata merupakan bentuk peran serta dan tanggung jawab masyarakat dalam pembangunan. Pelestarian lingkungan ini sejalan dengan konsep planet (kelestarian lingkungan) pada triple bottom line (Marnelly, 2012).

Keberlanjutan pengembangan pariwisata di desa Gadingan dapat dilaksanakan oleh warga masyarakat dengan terbentuknya Pokdarwis dan rencana pembentukan Badan Usaha Milik Desa (BumDes) yang menyokong pembangunan desa wisata Gadingan. Penyuluhan dan pelatihan yang telah dilakukan dapat dipergunakan sebagai modal awal masyarakat dalam melanjutkan pembangunan desa wisata Gadingan. Pendampingan kepada masyarakat, rintisan Pokdarwis, dan Pemerintah Desa Gadingan dilakukan secara berkelanjutan melalui aktivitas pemberdayaan.

\section{SIMPULAN}

Rintisan Pokdarwis yang telah dibentuk di desa Gadingan merupakan modal awal dalam pengembangan desa wisata Gadingan. Pokdarwis berperan aktif sebagai perencana, pengelola, dan inovator pariwisata di desa Gadingan. Pengembangan kapabilitas sumberdaya manusia di desa Gadingan menghasilkan pemetaan potensi wisata berupa pantai Gadingan sebagai wisata utama, pasar ikan, embung Gadingan, dan pelabuhan syahbandar sebagai wisata pelengkap, dan 
aktivitas Sholawat Nariyah sebagai wisata penunjang. Karakter sadar wisata ditunjukkan dengan rancangan atraksi wisata berupa spot foto di pantai Gadingan dan kegiatan bersih pantai yang merupakan bentuk peran serta dan tanggung jawab masyarakat dalam pemb angunan. Pendampingan kepada masyarakat di desa Gadingan masih terus dilakukan secara berkelanjutan melalui metode penyuluhan, pelatihan dan pendampingan.

\section{DAFTAR PUSTAKA}

A'inun, J., Krisnani, H. \& Darwis R. S. Pengembangan desa wisata melalui konsep community based tourism. Prosiding KS, 2 (3),

Aref, F., Gill, S. \& Aref, F. (2010). Tourism development in local communities: as a community development approach. Journal of American Science, 6 (2), 155-161.

Effendi, T.N. (2013). Budaya gotong masyarakat dalam perubahan sosial saat ini. Jurnal Pemikiran Sosial, 2(1), $1-18$.

Giampiccoli, A. \& Kalis, J.H. (2012). Community based tourism and local culture: the case of the amaMpondo. Jurnal Revista de Turismo $y$ Patrimonio Cultural, 10(1), 173-188.

Qiqi, D. \& Rova, L. (2014). Tourism development and human resources challenges (Gjirokastra region). European Journal of Sustainable Development, 3(3), 211-218.

Hadiwijoyo, S.S. (2012). Perencanaan pariwisata perdesaan berbasis masyarakat (sebuah konsep). Yogyakarta: Graha Ilmu.

Hermawan, Y. \& Suryono, Y. (2016). Partisipasimasyarakat dalam penyelenggaraan program-program pusat kegiatan belajar masyarakat ngudi kapinteran. Jurnal Pendidikan dan Pemberdayaan Masyarakat, 3(1), 97-108.

Kementerian Pariwisata dan Ekonomi Kreatif Republik Indonesia. (2012). Pedoman kelompok sadar wisata. Jakarta: Kemenpar \&Ekraf.
Sinh, B.D., Nga, V.T., Linh, V.T.H. \& Tuan, N.H. (2016). Stakeholder model application in tourism development in Cat Tien, Lam Dong. Journal of Advance Research in Social Sciences and humanities, 1(1), 73-95.

Marnelly, T.R. (2012). Corporate social responbility (CSR): tinjauan teori dan praktek di Indonesia. Jurnal Aplikasi Bisnis, 2(2), 50-59

Novaria, R. \& Rohimah, A. (20170. Pengembangan community based tourism sebagai strategi pemberdayaan masyarakat dan pemasaran pariwisata di Wonosalam kabupaten Jombang. Prosiding Seminar dan Call for Paper 20-21 Oktober 2017. Fakultas Ilmu Sosial dan Ilmu Politik Universitas Muhammadiyah Sidoarjo.

Primadany, S.R.. Mardiyono \& Riyanto. (2013). Analisis strategi pengembangan pariwisata daerah (studi pada Dinas Kebudayaan dan Pariwisata Daerah Kabupaten nganjuk). Jurnal Adiministrasi Publik, 1(4), 135-143.

Rani, D.P.M. (2014). Pengembangan potensi pariwisata kabupaten sumenep, madura, jawa timue (studi kasus: pantai lombang). Jurnal Politik Muda, 3(3), 412-421.

Sanusi, H. \& Hidayah, A.K. (2015) Pengkajian potensi desa dengan pendekatan partisipatif di desa mawai indah kecamatan batu ampar kabupaten kutai timur. Jurnal Agrifor, 14(2), 185-196.

Syafi'i, M. \& Suwandono, D. (2015). Perencanaan desa wisata dengan pendekatan community based tourism (CBT) di desa bedono, kecamatan sayung, kabupaten demak. Jurnal Ruang, 1(2), 51-60.

Wijaya, S.S., Zulkarnain \& Sopingi. (2016) Proses belajar kelompok sadar wisata (POKDARWIS) dalam pengembangan kampoeng ekowisata. Jurnal Pendidikan Nonformal, 11(2), 88-96.

Zakaria, F. \& Suprihardjo, R.D. (2014). Konsep pengembangan kawasan desa wisata di desa bandungan kecamatan pakong 
kabupaten pamekasan. Jurnal Teknik POMITS, 3(2), 245-249
Zulfanita \& Setiawan, B. (2015). Pengambangan desa wisata jatimalang berbasis industri kreatif. Jurnal Abdimas, 19(1), 1-8. 